\begin{tabular}{rl|l}
$\begin{array}{c}\text { Cellular Physiology } \\
\text { and Biochemistry }\end{array}$ & \begin{tabular}{l} 
Cell Physiol Biochem 2012;30:334-346 \\
\cline { 2 - 3 } DOI: 10.1159/000339068
\end{tabular} & $\begin{array}{l}\text { O 2012 S. Karger AG, Basel } \\
\text { www.karger.com/cpb }\end{array}$ \\
\cline { 2 - 3 } & Published online: June 25, 2012 & $1015-8987 / 12 / 0302-0334 \$ 38.00 / 0$
\end{tabular}

\title{
MAPK and JAK-STAT Signaling Pathways are Involved in the Oxidative Stress - Indu- ced Decrease in Expression of Surfactant Protein Genes
}

\author{
Sang-Kyu Park ${ }^{1,2,3}$ Mary K. Dahmer 1,2,3 Michael W. Quasney ${ }^{1,2,3}$ \\ ${ }^{1}$ Department of Pediatrics; ${ }^{2}$ Children's Research Institute, ${ }^{3}$ Human and Molecular Genetics Center, \\ Medical College of Wisconsin, Milwaukee
}

Key Words
Oxidative $\cdot$ Stress $\cdot$ Reactive oxygen species $\cdot$ Hydrogen peroxide $\cdot$ ERK $•$ p38 MAPK $•$ STAT3

Oxidative stress is generated by reactive oxygen species (ROS) including hydrogen peroxide $\left(\mathrm{H}_{2} \mathrm{O}_{2}\right)$, hydroxyl radical $(\cdot \mathrm{OH})$ and superoxide anion $\left(\mathrm{O}^{2-}\right)$, which are produced as by-products of cellular metabolism. An imbalance in cellular redox status is a potent pathogenic factor that contributes to various chronic inflammatory diseases. In this study, we demonstrate that $\mathrm{H}_{2} \mathrm{O}_{2}$ decreases surfactant protein A, B and ABCA3 mRNA level, and increases SP-D mRNA level in human pulmonary lung epithelial cells. The decreased mRNA level of SP-A and SP-B were significant with a maximum inhibition of 79 and $87 \%$, respectively by $150 \mu \mathrm{M} \mathrm{H} \mathrm{H}_{2}$ after 24 hrs of incubation. In addition, $A B C A 3$ mRNA level was decreased with a maximum inhibition of $55 \%$ by $150 \mu \mathrm{M} \mathrm{H}_{2} \mathrm{O}_{2}$ after 12 hrs of incubation. In contrast, $150 \mu \mathrm{M} \mathrm{H}_{2} \mathrm{O}_{2}$ caused the SP-D mRNA level to increase to $200 \%$ of control after $8 \mathrm{hrs}$ of incubation. The $\mathrm{H}_{2} \mathrm{O}_{2}$-induced gene repression or activation of SP-A, SP-B, SP-D and ABCA3 was blocked by pretreatment with the antioxidants N-acetyl-L-cysteine (NAC) and catalase. Furthermore, the inhibition of SP-A and SP-B was associated with reduced thyroid transcription factor -1 (TTF-1) DNA binding activity, and this reduced TTF-1 binding activity may be due to decreased TTF-1 protein expression level. The analyses of signal transduction pathways that may play a role in the regulation of gene expression by $\mathrm{H}_{2} \mathrm{O}_{2}$ using several specific inhibitors showed that U0126, an inhibitor of ERK1/2 upstream kinase MEK1/2, blocked both $\mathrm{H}_{2} \mathrm{O}_{2}$-induced inhibition of SP-A and SP-B gene expression, whereas SB203580, an inhibitor of p38 MAPK, partially blocked $\mathrm{H}_{2} \mathrm{O}_{2}$-mediated inhibition of SP-A gene expression but not SP-B expression. In contrast, AG-490, a specific inhibitor of JAK-STAT pathway, blocked $\mathrm{H}_{2} \mathrm{O}_{2}$-mediated inhibition of SP-B gene expression but not SP-A expression. Immunoblot analyses using specific phosphor-antibodies demonstrated that ERK1/2, p38 MAPK and STAT3 are phosphorylated by oxidative stress suggesting that $\mathrm{H}_{2} \mathrm{O}_{2}$-induced inhibition of SP-A and SP-B gene expression is associated with MAPK and JAKSTAT signaling pathway. These data, therefore, suggest that $\mathrm{H}_{2} \mathrm{O}_{2}$ affects SP-A and SP-B gene regulation by reducing TTF-1 DNA binding activity via MAPKs or STAT signaling pathways.

Copyright (C) 2012 S. Karger AG, Basel

Michael Quasney

Professor of Pediatrics
Children's Research Institute, Medical College of Wisconsin

Children's Hospital of Wisconsin

9000 W. Wisconsin, MS 681, Milwaukee, WI 53201 (USA)

Tel. +1414-266-3360,E-Mail mquasney@mcw.edu 


\begin{tabular}{rl|l}
$\begin{array}{c}\text { Cellular Physiology } \\
\text { and Biochemistry }\end{array}$ & $\begin{array}{l}\text { Cell Physiol Biochem 2012;30:334-346 } \\
\text { DOI: 10.1159/000339068 }\end{array}$ & $\begin{array}{l}\text { P 2012 S. Karger AG, Basel } \\
\text { Pww.karger.com/cpb }\end{array}$ \\
\cline { 2 - 3 } & Park/Dahmer/Quasney: Oxidative stress and surfactant gene expression
\end{tabular}

\section{Introduction}

Pulmonary surfactant, a mixture of phospholipid and protein synthesized exclusively by alveolar type II cells, is important in reducing surface tension at the air-liquid interface of lung alveoli [1]. The protein component of surfactant is composed of four surfactant-associated proteins, designated surfactant protein (SP)-A, SP-B, SP-C and SP-D. SP-A and SP-D are hydrophilic proteins and are believed to contribute to immune defense in the lung, whereas SP-B and SP-C are hydrophobic proteins that are responsible for the surface tension lowering properties of surfactant [2,3]. While SP-A, SP-B and SP-D are expressed in both alveolar type II and bronchiolar epithelial cells, the expression of SP-C is limited to alveolar type II cells. Decreased function of SP-A or SP-B or decreased expression in lung epithelial cells is associated with abnormal pulmonary function and fetal diseases in both humans and mice $[4,5]$. Lung epithelial cells are exposed to oxidative stress due to oxidants from both the outside environment and from normal cellular processes. Oxidative stress refers to cellular damage caused by reactive oxygen species (ROS) such as hydrogen peroxide $\left(\mathrm{H}_{2} \mathrm{O}_{2}\right)$, hydroxyl radical $(\mathrm{OH})$ and superoxide anion $\left(\mathrm{O}^{2-}\right)$. The level of oxidative stress in the lung also increases with inflammation as activated macrophages and neutrophils generate toxic oxygen products. ROS have been implicated in the onset and progression of a number of chronic and acute inflammatory diseases such as asthma, chronic obstructive pulmonary disease (COPD), respiratory distress syndrome (RDS) and acute lung injury [6-9]. ROS activate multiple signaling pathways including mitogen-activated protein kinase (MAPK) [10] and Janus kinase (JAK)/ signal transducers and activators of transcription (STAT) [11,12] pathways.

ROS can inactivate surfactant proteins $[13,14]$ and cellular oxidation has been reported to decrease SP-A and SP-B mRNA levels [15]. The molecular mechanism by which oxidative stress affects SP-A and SP-B-mRNA levels has not been explored. To address this issue, we exposed human pulmonary adenocarcinoma NCI-H441 cells to $\mathrm{H}_{2} \mathrm{O}_{2}$ mediated oxidative stress, examined effects on the expression of surfactant related proteins, and performed studies to elucidate the molecular mechanism of this effect.

\section{Materials and Methods}

\section{Materials}

Human pulmonary adenocarcinoma NCI-H441 cells were purchased from American Type Culture Collection (Rockville, MD). Cell culture media, antibiotics, HEPES, fetal bovine serum (FBS), SuperScript firststrand synthesis system for cDNA synthesis and Trizol reagent were purchased from Invitrogen (Carlsbad, CA). $\mathrm{H}_{2} \mathrm{O}_{2}$, N-Acetyl-L-cysteine (NAC), and catalase was obtained from Sigma (St Louis, MO). RNeasy mini kit and Qiaquick PCR purification kit were purchased from Qiagen (Valencia, CA). iQ SYBR Green supermix kit and 96-well plates for Quantitative Real-Time (qRT-PCR), SDS-polyacrylamide electrophoresis gel, nitrocellulose membrane and DC protein assay kits were purchased from Bio-Rad (Hercules, CA). BCA protein assay kits were purchased from Pierce (Rockford, IL). U0126 was purchased from Promega (Madison, WI).

SP600125 and AG490 were purchased from Calbiochem (San Diego, CA). Complete mini protease inhibitor cocktail and PhosSTOP phosphatase inhibitor cocktail were purchased from Roche Applied Science (Indianapolis, IN). SB203580 was purchased from BioMol (Plymouth Meeting, PA). Antibody for detection of actin was purchased from Santa Cruz Biotechnology (Santa Cruz, CA) and anti-TTF-1 antibody was purchased from Seven Hills Bioreagents (Cincinnati, $\mathrm{OH}$ ). Antibodies for detection of phosphorylated protein kinases, ERK1/2, p38 MAPK, STAT3 (Tyr705), as well as total ERK1/2, p38 MAPK, STAT3, and HRPconjugated secondary antibody were purchased from Cell Signaling Technology (Beverly, MA). The enhanced chemiluminescence Western blot detection system was purchased from Amersham Pharmacia Biotech (Piscataway, NJ).

\section{Methods}

Cell Culture and Treatment. Human pulmonary adenocarcinoma NCI-H441 cells with characteristics of bronchiolar (Clara) epithelial cells were maintained in RPMI 1640 medium supplemented with penicillin $(100 \mathrm{U} / \mathrm{ml})$, streptomycin $(100 \mu \mathrm{g} / \mathrm{ml}), 25 \mathrm{mM}$ HEPES, amphotericin B $(0.25 \mu / \mathrm{ml})$ and $10 \%$ fetal bovine serum (FBS) in a humidified atmosphere of $5 \% \mathrm{CO}_{2}$ at $37^{\circ} \mathrm{C}$. For experiments, cells (passage $3-10$ ) were seeded 


\section{Cellular Physiology and Biochemistry}

Cell Physiol Biochem 2012;30:334-346

\begin{tabular}{l|l}
\hline DOI: $10.1159 / 000339068$ & C 2012 S. Karger AG, Basel
\end{tabular}

Published online: June 25, 2012

www.karger.com/cpb

Table 1. Primers used in quantitative real-time PCR ( $q P C R$ )

\begin{tabular}{llll}
\hline Genes name & Accession number & Forward primer & Reverse primer \\
\hline SP-A & NM006926 & 5'-TGAAGGACGTTTGTGTTGGAAGCC-3' & 5'-TTCCCAGGAGGACATGGTGTTTCT-3' \\
SP-B & NM198843 & 5'-TAGGGCATTGCCTACAGGAAGTCT-3' & 5'-ATGGCCTCCTTGGCCATCTTGTTA-3' \\
SP-D & NM003019 & 5'-AAAGGGAGAAAGTGGGCTTCCAGA-3' & 5'-ACACTTTGGCCATTTGGGAAGAGC-3' \\
ABCA3 & AB070929 & 5'-AGTGCGCAGGGCACTTGT-3' & 5'-GGACGAGCAGTTGTCGTACCTA-3' \\
GAPDH & AB062273 & 5'-CATGTTCGTCATGGGTGTGAACCA-3' & 5'-AGTGATGGCATGGACTGTGGTCAT-3' \\
TTF-1 & NM001079668 & 5'-GCGACGCTTCAAGCAACAGAAGTA-3' & 5'-TTGTCCTTGGCCTGGCGCTTCATTT-3' \\
\hline
\end{tabular}

into $60 \mathrm{~mm}$ dishes at a density of $5 \times 10^{5}$ or $100 \mathrm{~mm}$ dishes at a density of $1.5 \times 10^{6}$ per dish, cultured overnight, washed with warm PBS and then cultured overnight in serum-free and phenol red-free RPMI 1640. The medium was then changed to fresh serum-free and phenol red-free RPMI 1640 that contained various concentrations of $\mathrm{H}_{2} \mathrm{O}_{2}$. In some experiments, cells were pretreated with the antioxidants N-acetyl-L-cysteine (NAC) or catalase, or with specific protein kinase inhibitors (U0126, SB203580, SP600125, AG490), for $1 \mathrm{~h}$ at $37^{\circ} \mathrm{C}$ before treatment with $\mathrm{H}_{2} \mathrm{O}_{2}$.

Cell Viability. Cell viability was examined using 3-(4,5-dimethylthiazol-2-yl)-5-(3-carboxymethoxyphenyl)-2- (4-sulfophenyl)-2H-tetrazolium, inner salt (MTS) according to the manufacturer's instructions (Promega). The MTS reagent is reduced by metabolically active cells into a colored formazan product whose absorbance is then measured. In brief, MTS solution was added to wells of a 96-well microtiter plate, and the cells were incubated for $2 \mathrm{~h}$. The absorbance at $490 \mathrm{~nm}$ was then measured.

RNA isolation and quantitative real time RT-PCR. Total RNA was isolated from cells using Trizol reagent according to manufacturer's instruction, treated with Turbo DNase to remove any contaminating DNA, and purified using RNeasy mini kit. Total RNA was used to generate cDNA with the SuperScript first-strand synthesis system. A standard $10 \mu \mathrm{l}$ reaction contained $1 \mu \mathrm{g}$ RNA, $400 \mathrm{ng}$ random hexamers, and $0.5 \mathrm{mM}$ dNTPs. The mixture was incubated at $65^{\circ} \mathrm{C}$ for $5 \mathrm{~min}$, then on ice for $1 \mathrm{~min}$. $5 \mathrm{x}$ reverse transcriptase (RT) buffer (1x final concentration), dithiothreitol $(10 \mathrm{mM})$, ribonuclease inhibitor and 50 units of SuperScript III RT were added and the reaction was incubated at $22^{\circ} \mathrm{C}$ for $10 \mathrm{~min}$, then at $50^{\circ} \mathrm{C}$ for $50 \mathrm{~min}$, and finally at $70^{\circ} \mathrm{C}$ for 15 min. Quantitative real time RT-PCR (qRT-PCR) reactions were performed in 96-well plates using the iQ SYBR Green supermix kit and consisted of incubations at $95^{\circ} \mathrm{C}$ for $1.5 \mathrm{~min}$ followed by 40 amplification cycles of $95^{\circ} \mathrm{C}$ for $15 \mathrm{sec}$ and $55^{\circ} \mathrm{C}$ for $30 \mathrm{sec}$. Primers for the qRT-PCR were purchased by Sigma and the sequences of the primers are shown in Table 1. The cycle threshold (CT) for each reaction (indicating the amount of PCR product and level of mRNA expression) was determined using the $\mathrm{iCycler}_{\mathrm{iQ}}^{\mathrm{TM}}$ Detection System. All samples were assayed in triplicate and the expression levels were normalized against that of endogenous glyceraldehyde 3-phosphate dehydrogenase (GAPDH).

Chromatin Immunoprecipitation (ChIP) assay. The ChIP assay was performed as previously described [16] with some modifications. For each condition five $10 \mathrm{~cm}$ plates were seeded with $1.5 \times 10^{6}$ cells and cultured overnight in normal culture medium. The following day cultures were washed with PBS and incubated overnight with serum-free and phenol-free RPMI and then incubated for $24 \mathrm{~h}$ with or without $\mathrm{H}_{2} \mathrm{O}_{2}$. After incubation cells were fixed with $1 \%$ formaldehyde in serum-free and phenol red-free RPMI for 10 min at room temperature, washed with PBS, and subsequently quenched with $10 \mathrm{ml}$ of $0.125 \mathrm{M}$ glycine in serum-free and phenol red-free RPMI for 5 min at room temperature. Cultures were then washed with PBS and cells were harvested in $1 \mathrm{ml}$ PBS with freshly added protease inhibitor cocktail, per dish. Harvested cells from the 5 plates were combined, and pelleted by centrifugation. Cross-linked cell pellets were resuspended in $250 \mu \mathrm{l}$ of lysis buffer (25 mM Tris-Cl, pH 8.1, $140 \mathrm{mM} \mathrm{NaCl}, 1 \%$ Triton X-100, 0.1\% SDS, 3 mM EDTA and protease inhibitor cocktail) and incubated on ice for $10 \mathrm{~min}$. Fragmentation of chromosomes was achieved by sonication using a Sonicator S-4000 (pulsed for $30 \mathrm{sec}$ on and $1 \mathrm{~min}$ off 24 times at $85 \%$ and 12 times at $100 \%$ duty cycle) yielding DNA fragments with an average length $0.2-1.5 \mathrm{~kb}$. Cell debris was removed by centrifugation at $20,000 \mathrm{xg}$ for $10 \mathrm{~min}$ at $4^{\circ} \mathrm{C}$. The supernatant was removed and brought to a final volume of $300 \mu \mathrm{l}$ with lysis buffer. 5-10 $\mu \mathrm{l}$ of supernatant was reserved for input DNA. For immunoprecipitation, the remaining supernatant was equally divided between two tubes and either $7 \mu \mathrm{l}$ of monoclonal mouse TTF-1 antibody or $7 \mu \mathrm{l}$ of mouse IgG (used as a negative control), was added, followed by incubation overnight at $4^{\circ} \mathrm{C}$. Sonicated salmon sperm DNA/Protein A agarose beads were then added to the samples, incubation was continued at $4^{\circ} \mathrm{C}$ for $2 \mathrm{~h}$, and beads were pelleted by a brief centrifugation. Pellets were washed once with $150 \mu \mathrm{l}$ of TSE $150 \mathrm{mM} \mathrm{NaCl}$ buffer (0.1\% SDS, 1\% Triton X-100, 2 mM EDTA, 20 mM Tris-HCl, pH 8.1 and 150 $\mathrm{mM} \mathrm{NaCl}$ ), once with $150 \mu \mathrm{l}$ of TSE $500 \mathrm{mM} \mathrm{NaCl}$ buffer $(0.1 \%$ SDS, 1\% Triton X-100, $2 \mathrm{mM}$ EDTA, $20 \mathrm{mM}$ Tris-HCl, pH 8.1 and $500 \mathrm{mM} \mathrm{NaCl})$, once with LiCl buffer solution III ( $0.25 \mathrm{M} \mathrm{LiCl}, 1 \% \mathrm{NP}-40,1 \%$ deoxycholate, $1 \mathrm{mM}$ EDTA and $10 \mathrm{mM}$ Tris-Cl, pH 8.1) and twice with TE buffer at $4^{\circ} \mathrm{C}$ with gentle agitation. After washing, immunocomplexes were eluted off the beads by incubation at room temperature with $200 \mu \mathrm{l}$ of $1 \%$ SDS and $0.1 \mathrm{M} \mathrm{NaHCO}_{3}$. The eluate from the immunoprecipitation and the input sample were incubated at $65^{\circ} \mathrm{C}$ overnight to reverse protein-DNA cross-linking followed by DNA extraction using the Qiaquick PCR 


\begin{tabular}{rl|l}
$\begin{array}{c}\text { Cellular Physiology } \\
\text { and Biochemistry }\end{array}$ & $\begin{array}{l}\text { Cell Physiol Biochem 2012;30:334-346 } \\
\text { DOI: 10.1159/000339068 }\end{array}$ & $\begin{array}{l}\text { P 2012 S. Karger AG, Basel } \\
\text { Pww.karger.com/cpb }\end{array}$ \\
\cline { 2 - 3 } & Park/Dahmer/Quasney: Oxidative stress and surfactant gene expression
\end{tabular}

purification kit. The DNA was then used as template for quantitative PCR analysis using primers specific to either the SP-A or SP-B TTF-1 binding sites in the respective promoter regions. Results are expressed as a percent of input DNA.

\section{Immunoblot analysis}

Sample preparation. Cells were cultured in $10 \mathrm{~cm}$ dishes and treated with or without $\mathrm{H}_{2} \mathrm{O}_{2}$ as described above under the ChIP assay except that plates were not pooled before analysis. After treatment, $10 \mathrm{~cm}$ diameter dishes were washed twice with ice-cold PBS, harvested into $1 \mathrm{ml}$ PBS, and cells pelleted at 1000 $\mathrm{x} g$ for 5 min.

Nuclear extracts to be used for immunoblotting of TTF-1 protein were prepared as described previously [17]. In brief, the cell pellet was lysed by resuspension in $100 \mu$ of lysis buffer A (10 mM HEPES, pH 7.9, $10 \mathrm{mM} \mathrm{KCl}, 0.1 \mathrm{mM}$ EDTA, $1.5 \mathrm{mM} \mathrm{MgCl}$, 0.2\% Nonidet P-40, $1 \mathrm{mM}$ dithiothreitol and $0.5 \mathrm{mM}$ PMSF), and incubated on ice for $5 \mathrm{~min}$. The sample was centrifuged at $1000 \mathrm{xg}$ for $5 \mathrm{~min}$ and the nuclear pellet was resuspended in $100 \mu \mathrm{l}$ of buffer B (20 mM HEPES, pH 7.9, $420 \mathrm{mM} \mathrm{NaCl}, 0.1 \mathrm{mM}$ EDTA, $1.5 \mathrm{mM} \mathrm{MgCl}, 25 \%$ glycerol, $1 \mathrm{mM}$ dithiothreitol, $0.5 \mathrm{mM}$ PMSF), and nuclear proteins were extracted by incubation for $10 \mathrm{~min}$ with occasional gentle vortexing. The sample was then centrifuged at 20,000 x g for $10 \mathrm{~min}$ and the supernatant was recovered and used for immunoblotting. Protein concentration in the supernatant was determined using the DC protein assay kit.

Cell pellets to be used for immunoblotting of protein kinases were resuspended in $100 \mu \mathrm{l}$ of Cell Lysis Buffer with $0.5 \mathrm{mM}$ phenylmethanesulfonylfluoride (PMSF), Complete Protease Inhibitor and PhosSTOP for $10 \mathrm{~min}$ on ice. After brief sonication, the lysate was cleared by centrifugation at 20,000 x $\mathrm{g}$ for $10 \mathrm{~min}$, and supernatant was used for immunoblotting. Protein concentration was determined using the BCA protein assay kit.

Immunoblotting protocol. Nuclear extracts described as prepared above were used for immunoblotting with anti TTF- 1 antibody. Lysates containing protein were boiled for $5 \mathrm{~min}$ in SDS sample buffer and an equal amount of protein $(20-50 \mu \mathrm{g})$ loaded in each lane of a $10 \%$ or $12 \%$ SDS-polyacrylamide gel as indicated. After gel electrophoresis proteins were transferred to a nitrocellulose membrane. Membranes were incubated for $1 \mathrm{~h}$ in $0.1 \%$ Tween - phosphate buffered saline (PBST) containing 5\% nonfat milk powder for blocking and then incubated with primary mouse monoclonal anti-TTF-1 antibody (1:1000 dilution) in fresh blocking solution overnight at $4^{\circ} \mathrm{C}$. After washing three times for $10 \mathrm{~min}$ in $0.1 \%$ PBST membranes were incubated with the corresponding horseradish peroxidase (HRP)-conjugated secondary antibody for $1 \mathrm{~h}$ at room temperature. Blots were developed using the enhanced chemiluminescence Western blot detection system and quantified with a STORM 860 PhosphoImager system. Blots were then stripped using 1 M glycine, washed with PBST and immunoblotted and visualized as described above for TTF-1 except that anti-actin antibody (1:1000) was used.

To detect protein kinases, analysis was performed as described above except that membranes were incubated with $0.1 \%$ Tween - Tris buffered saline (TBST) containing 5\% nonfat milk powder for blocking incubation with antibody. For phosphorylated kinases primary rabbit phosphospecific antibodies to pERK1/2, p-p38 MAPK, and pSTAT3 (Tyr705) were used. For detection of total kinases (phosphorylated and nonphosphorylated) rabbit antibodies to ERK1/2 and p38 MAPK antibodies, and mouse antibody to STAT3 was utilized. All antibodies were from Cell Signaling Technology and were used at 1:1000 dilution and immunoblotting analysis was performed as described above except for the use of in $0.1 \%$ TBST (rather than $0.1 \%$ PBST). Blots were stripped and probed with additional antibodies (actin, total ERK1/2, p38 MAPK, STAT3) as described above.

\section{Statistical analyses}

The statistical test used to determine significance was dependent upon the specific experiment and is indicated in figure legends. Statistical tests utilized included the paired t-test, and repeated-measures oneway ANOVA with either a Dunnett or Tukey post test. $\mathrm{p}<0.05$ was considered significant.

\section{Results}

$\mathrm{H}_{2} \mathrm{O}_{2}$ Decreases Surfactant Protein $A, B$ and ABCA3 mRNA levels, but increases the level of $S P$-D $m R N A$

To investigate the potential impact of oxidative stress on regulation of surfactant related genes, we examined the effect of $\mathrm{H}_{2} \mathrm{O}_{2}$ on expression of SP-A, SP-B, SP-D, and ABCA3 in H441 human adenocarcinoma pulmonary epithelial cells. (Since $\mathrm{H} 441$ cells do not express SP-C [18], the effect of $\mathrm{H}_{2} \mathrm{O}_{2}$ on SP-C expression was not examined). $\mathrm{H}_{2} \mathrm{O}_{2}$ treatment $(150 \mu \mathrm{M})$ of 


\section{Cellular Physiology and Biochemistry \\ Cell Physiol Biochem 2012;30:334-346 \\ \begin{tabular}{l|l}
\hline DOI: $10.1159 / 000339068$ & C 2012 S. Karger AG, Basel \\
Published online: June 25, 2012 & www.karger.com/cpb
\end{tabular}}

338

Fig. 1. Effects of $\mathrm{H}_{2} \mathrm{O}_{2}$ on SP-A, SP-B, SP-D, and $A B C A 3$ mRNA levels in $\mathrm{H} 441$ cells. After the indicated treatments total RNA was isolated, and qRT-PCR was performed as described under Methods to determine mRNA level. Data are normalized to glyceraldehyde 3-phosphate dehydrogenase (GAPDH) mRNA level and expressed as a percent of untreated controls. A: H441 cells were incubated in the presence or absence of $150 \mu \mathrm{M} \mathrm{H}_{2} \mathrm{O}_{2}$ for the indicated time periods. Statistical significance was determined using a repeated measures one-way ANOVA with a Dunnett post test. For SP-A, $12(\mathrm{p}<0.05)$ and $24(\mathrm{p}<0.01)$ h values were significantly different than the $4 \mathrm{~h}$ value. For SP-B, 12 and $24 \mathrm{~h}$ values were significantly different $(\mathrm{p}<0.01)$ than the $4 \mathrm{~h}$ value. For SP-D, the $24 \mathrm{~h}$ value was significantly different $(\mathrm{p}<0.05)$ than the $4 \mathrm{~h}$ value. For ABCA3, 8, 12, and 24 $h$ values were statistically different $(\mathrm{p}<0.01)$ than the $4 \mathrm{~h}$ value. $\mathrm{B}$ : $\mathrm{H} 441$ cells were treated with various concentrations of $\mathrm{H} 2 \mathrm{O} 2$ for either $24 \mathrm{hr}$ (SP-A and SP-B), or $12 \mathrm{hr}$ (ABCA3). Statistical significance was determined using a repeated measures one-way ANOVA with a Dunnett post test. For the SP-A and SP-B results all values were significantly different than the value for $10 \mu \mathrm{M} \mathrm{H}_{2} \mathrm{O}_{2}$ with $\mathrm{p}<0.01$ for all except SP-A at $30 \mu \mathrm{M}$ where $\mathrm{p}<0.05$. For ABCA3, all values at concentrations at or above $50 \mu \mathrm{M}$ are statistically different from the $10 \mu \mathrm{M}$ value $(\mathrm{p}<0.05)$. Data shown are the means \pm S.D. of three separate experiments.

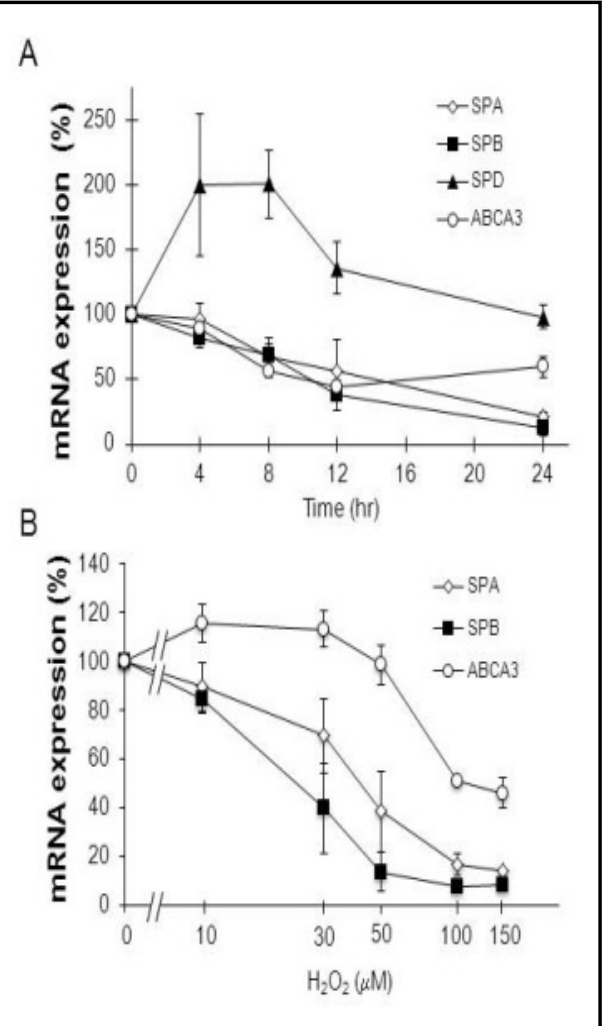

H441 cells resulted in a time-dependent reduction in SP-A and SP-B mRNA levels with the maximal effect at $24 \mathrm{~h}$ when SP-A and SP-B mRNA levels were decreased to $\sim 15-20 \%$ of untreated controls (Fig. 1A). $\mathrm{H}_{2} \mathrm{O}_{2}$ also decreased ABCA3 mRNA levels, however, the maximal decrease was observed at $12 \mathrm{~h}$ and ABCA3 mRNA was only reduced to $\sim 50 \%$ of untreated controls (Fig. 1A). In contrast, the SP-D mRNA level was increased to $\sim 200 \%$ at early time points ( 4 and $8 \mathrm{~h}$ ) after treatment and then returned to control levels by $24 \mathrm{~h}$ (Fig. 1A). The inhibition of $\mathrm{H}_{2} \mathrm{O}_{2}$ was concentration dependent as demonstrated in Figure 1B. There was a decrease in SP-A, SP-B and ABCA3 mRNA levels with a maximal effect observed at 100-150 $\mu \mathrm{M} \mathrm{H}_{2} \mathrm{O}_{2}$. As we were primarily interested in examining the pathways involved in the inhibition of expression of surfactant related genes, we only further examined $\mathrm{H}_{2} \mathrm{O}_{2}$ inhibition of SP-A and SP-B.

To examine whether $\mathrm{H}_{2} \mathrm{O}_{2}$ affected cell viability the effect of $150 \mu \mathrm{M} \mathrm{H}_{2} \mathrm{O}_{2}$ on number of viable cells after 4, 8, 12 and $24 \mathrm{~h}$ of treatment was determined as described under Methods. Cell viability did not decrease significantly with $\mathrm{H}_{2} \mathrm{O}_{2}$ treatment over the time examined (data not shown) indicating that there was no significant cytotoxicity with $150 \mu \mathrm{M} \mathrm{H}_{2} \mathrm{O}_{2}$ treatment. In addition, neither total RNA yield nor GAPDH mRNA levels were significantly altered at the various concentrations of $\mathrm{H}_{2} \mathrm{O}_{2}$ used at any of the time points (data not shown).

\section{Antioxidants block $\mathrm{H}_{2} \mathrm{O}_{2}$-mediated effects on $S P-A, S P-B$, and $A B C A 3 \mathrm{mRNA}$}

Previous work examining the effects $\mathrm{H}_{2} \mathrm{O}_{2}$ on various cell types has used the antioxidant $\mathrm{N}$-acetyl cysteine or catalase to help determine whether the effects of $\mathrm{H}_{2} \mathrm{O}_{2}$ are related to its oxidative effects $[19,20]$. To determine whether the decreased expression of SP-A, SP-B and ABCA3 was specific to the oxidative effects of $\mathrm{H}_{2} \mathrm{O}_{2}$, we pretreated $\mathrm{H} 441$ cells with the antioxidants $\mathrm{N}$-acetyl cysteine $(\mathrm{NAC}, 10 \mathrm{mM})$ or catalase $(100 \mathrm{U} / \mathrm{ml})$. These agents either completely prevented or significantly attenuated the $\mathrm{H}_{2} \mathrm{O}_{2}$-mediated decrease in SP-A, SP-B, and $A B C A 3$ mRNA expression (Fig. 2A-C). These results suggest that the observed effect of $\mathrm{H}_{2} \mathrm{O}_{2}$ on SP-A, SP-B, and ABCA3 gene expression is the result of the oxidative effects of $\mathrm{H}_{2} \mathrm{O}_{2}$. 


\section{Cellular Physiology $\quad$ Cell Physiol Biochem 2012;30:334-346 and Biochemistry

Fig. 2. Effect of antioxidants on the $\mathrm{H}_{2} \mathrm{O}_{2}$-induced decreased in SP-A, SP-B, and ABCA3 mRNA levels. H441 cells were treated with or without $\mathrm{N}$-acetyl-L-cysteine (NAC) or catalase for $1 \mathrm{~h}$ before incubation for 12 (ABCA3) or 24 (SP-A, SP-B) hours with or without $\mathrm{H}_{2} \mathrm{O}_{2}$. RNA was isolated, and qRT-PCR was performed as described under Methods to determine mRNA level. Data are normalized to glyceraldehyde 3-phosphate dehydrogenase (GAPDH) mRNA level and expressed as a percent of untreated controls. Data shown are the means \pm S.D. of three separate experiments. Statistical significance was determined using a repea-

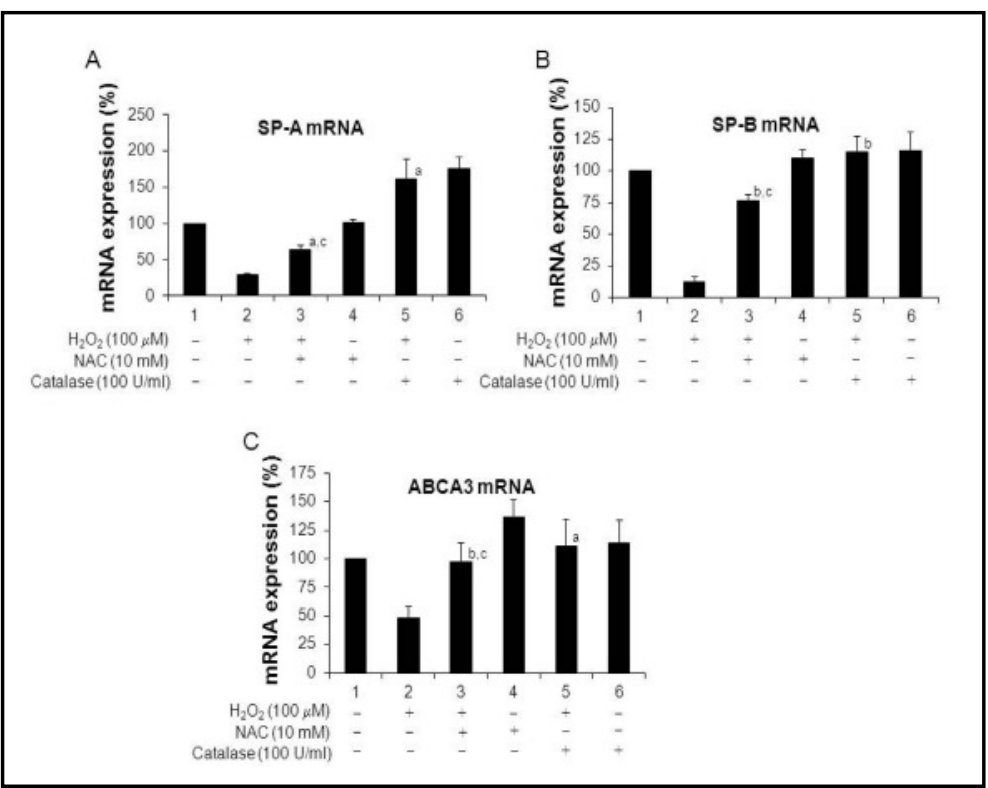
ted measures one-way ANOVA with a Tukey post test. a, $\mathrm{p}<0.01, \mathrm{~b}, \mathrm{p}<0.001$, compared to $\mathrm{H}_{2} \mathrm{O}_{2}$ only; $\mathrm{c}, \mathrm{p}<0.01$ compared to NAC only.

Fig. 3. Effect of $\mathrm{H}_{2} \mathrm{O}_{2}$ on TTF1 binding to SP-A and SP-B promoter regions. H441 cells were treated with or without $\mathrm{N}$-acetyl-L-cysteine (NAC) for $1 \mathrm{~h}$ before incubation for 24 hours with or without $\mathrm{H}_{2} \mathrm{O}_{2}$. ChIP analysis was performed as described under Methods using anti-TTF-1 antibody or normal IgG as a negative control. Input DNA (soluble chromatin before immunoprecipitation) was used as a positive control. A: Ethidium bromide staining of one representative experiment showing amplified products specific for SP-A (top) and SP-B (bottom) promoter regions af-

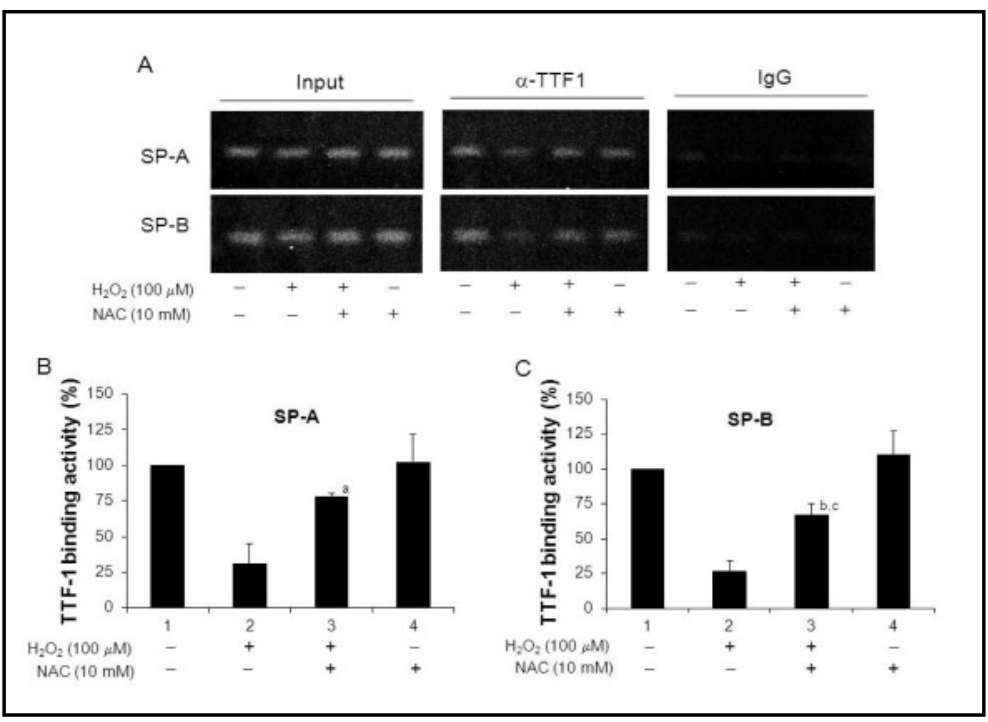
ter ChIP analysis. B and C: The amount of TTF-1 binding to SP-A and SP-B promoter regions was quantitated by qPCR of precipitated DNA. Results are expressed as a percent of the binding observed in untreated cells. Data shown are the means \pm S.D. of three separate experiments. Statistical significance was determined using a repeated measures one-way ANOVA with a Tukey post test. a, $\mathrm{p}<0.05, \mathrm{~b}, \mathrm{p}<0.01$, compared to $\mathrm{H}_{2} \mathrm{O}_{2}$ only; c, $\mathrm{p}<0.01$ compared to NAC only.

\section{$\mathrm{H}_{2} \mathrm{O}_{2}$ reduces TTF- 1 binding to SP-A and SP-B promoter regions}

Thyroid transcription factor 1 (TTF-1/NKX2.1, hereafter referred to as TTF-1), a member of Nkx family of homeodomain transcription factors, is involved in transcriptional regulation of a number of genes and is essential for the transcriptional regulation of SP-A, SP-B and $\mathrm{ABCA} 3$ [21-23]. To determine whether $\mathrm{H}_{2} \mathrm{O}_{2}$ alters TTF-1 DNA binding to the promoter regions of SP-A and SP-B, we performed chromatin immunoprecipitation (ChIP) assays using anti-TTF-1 antibody. As shown in Figure 3, $\mathrm{H}_{2} \mathrm{O}_{2}(100 \mu \mathrm{M})$ decreased TTF-1 binding to the SP-A and SP-B promoter regions by $\sim 75 \%$. In addition, the $\mathrm{H}_{2} \mathrm{O}_{2}$ induced decreased in TTF-1 binding was attenuated by pretreatment with the antioxidant NAC. These results strongly suggest that the $\mathrm{H}_{2} \mathrm{O}_{2}$ induced decrease in SP-A and SP-B gene expression is due, at least in 


\section{Cellular Physiology $\quad$ Cell Physiol Biochem 2012;30:334-346 and Biochemistry

\begin{tabular}{l|l}
\hline DOI: $10.1159 / 000339068$ & C 2012 S. Karger AG, Basel \\
www.karger.com/cpb
\end{tabular}

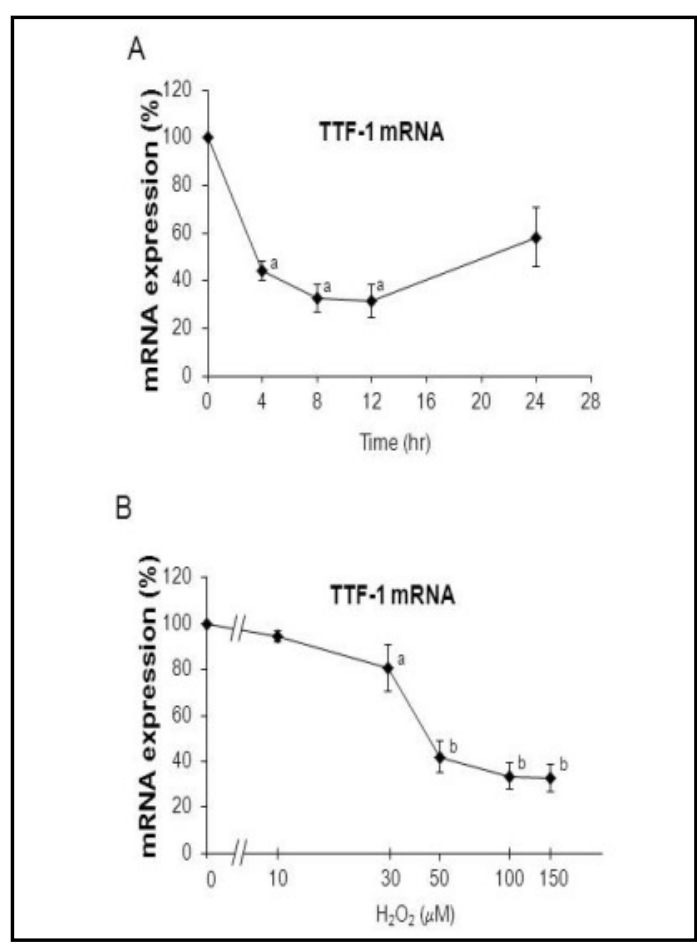

Fig. 4. Effect of $\mathrm{H}_{2} \mathrm{O}_{2}$ on TTF-1 gene expression in H441 cells. After the indicated treatments total RNA was isolated, and qRT-PCR was performed as described under Methods to determine TTF-1 mRNA level. Data are normalized to glyceraldehyde 3-phosphate dehydrogenase (GAPDH) mRNA level and expressed as a percent of untreated controls. A: H441 cells were incubated in the presence or absence of 150 $\mu \mathrm{M} \mathrm{H}_{2} \mathrm{O}_{2}$ for the indicated time periods. Significance was determined using a paired t test. a, $\mathrm{p}<0.05$ versus untreated controls. B: $\mathrm{H} 441$ cells were treated with various concentrations of $\mathrm{H}_{2} \mathrm{O}_{2}$ for $8 \mathrm{hr}$. Significance was determined using a repeated measures one-way ANOVA with a Dunnett post test. a, $\mathrm{p}<0.05$, b, $\mathrm{p}<0.01$ compared to the $10 \mu \mathrm{M}$ value. Data shown are the means \pm S.D. of three separate experiments.

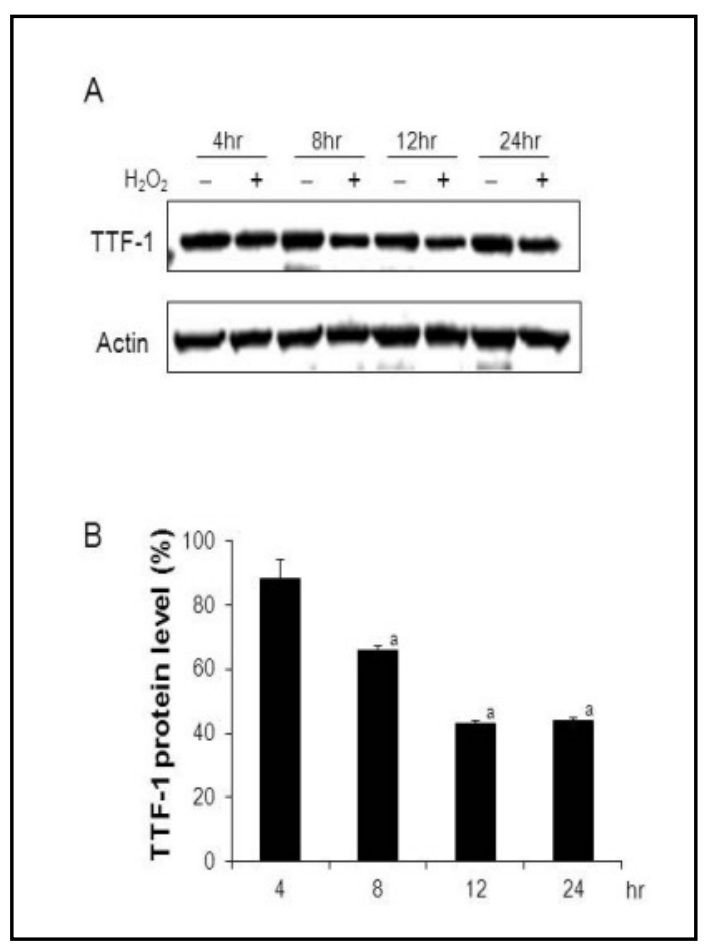

Fig. 5. Effect of $\mathrm{H}_{2} \mathrm{O}_{2}$ on TTF-1 protein expression. $\mathrm{H} 441$ cells were treated with or without $\mathrm{H}_{2} \mathrm{O}_{2}$ for 4-24 hr, and nuclear extracts were prepared. Equal amount of protein lysates $(\sim 30 \mu \mathrm{g})$ were analyzed by immunoblotting as described under Methods to detect TTF-1 protein. A: Results from one representative immunoblot. B: Protein bands were quantified using a STORM 860 phosphorImager and normalized to actin. Results are expressed as a percent of the 4 hour untreated control. Data shown are the means \pm S.D. of three separate experiments. Significance was determined using a repeated measures one-way ANOVA with a Dunnett post test. a, $\mathrm{p}<0.01$, compared to treatment with $\mathrm{H} 2 \mathrm{O} 2$ for $4 \mathrm{~h}$.

part, to reduced TTF-1 binding to the SP-A and SP-B promoters.

\section{$\mathrm{H}_{2} \mathrm{O}_{2}$ reduces TTF- 1 mRNA and protein levels}

To determine whether the reduction in TTF- 1 binding activity caused by $\mathrm{H}_{2} \mathrm{O}_{2}$ was due to decreased expression of TTF- 1 , the effect of $\mathrm{H}_{2} \mathrm{O}_{2}$ on TTF- 1 expression was examined. $\mathrm{H}_{2} \mathrm{O}_{2}$ treatment of $\mathrm{H} 441$ cells resulted in a time- and concentration-dependent decrease in TTF-1 mRNA levels with the maximal reduction observed by $8 \mathrm{~h}(\sim 70 \%)$; by $24 \mathrm{~h}$ TTF-1 mRNA levels begin to increase towards untreated controls (Fig. 4A). As shown in Fig. 4B, The observed concentration dependence is similar to that observed for effects on SP-A, SP-B and ABCA3 mRNA levels with 100-150 $\mu \mathrm{M}$ showing a maximal effect. Pretreatment with the antioxidants NAC or catalase completely prevented this reduction (data not shown). Immunoblotting using anti TTF- 1 antibody was performed to determine whether $\mathrm{H}_{2} \mathrm{O}_{2}$ also decreased TTF-1 protein levels. As shown in Figure $5, \mathrm{H}_{2} \mathrm{O}_{2}$ decreased TTF-1 protein levels over time with a maximal decrease of $\sim 60 \%$ at $12 \mathrm{~h}$, suggesting that reduced TTF-1 protein level contributed to the $\mathrm{H}_{2} \mathrm{O}_{2}$-mediated reduction in SP-A, SP-B and ABCA3 mRNA levels. 


\section{Cellular Physiology \\ Cell Physiol Biochem 2012;30:334-346 \\ and Biochemistry

\begin{tabular}{l|l}
\hline DOI: 10.1159/000339068 & $\begin{array}{l}\text { C) } 2012 \text { S. Karger AG, Basel } \\
\text { www.karger.com/cpb }\end{array}$ \\
\hline Published online: June 25,2012 &
\end{tabular}
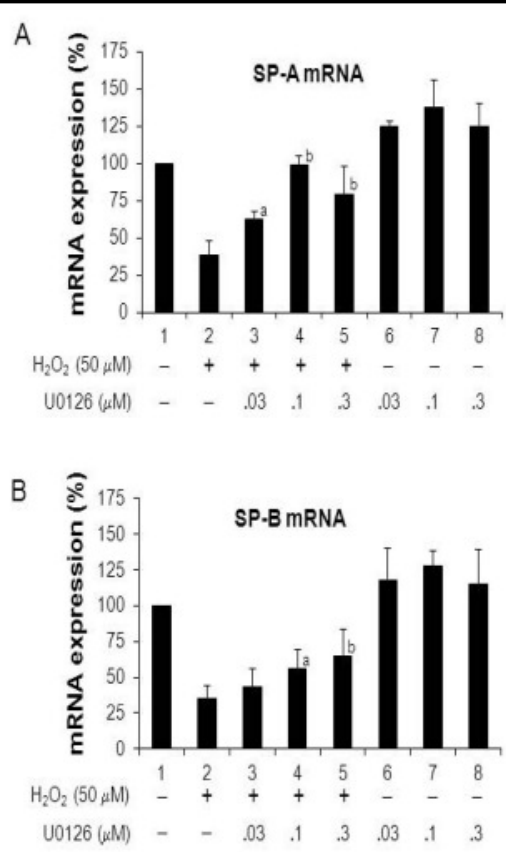

Fig. 6. Effect of U0126 on the $\mathrm{H}_{2} \mathrm{O}_{2}$-induced decrease in SP-A and SP-B gene expression. H441 cells were treated for 1 hour with various concentrations of U0126 and then incubated for an additional 24 hours in the absence or presence of $\mathrm{H}_{2} \mathrm{O}_{2}$. Total RNA was then isolated, and qRT-PCR was performed as described under Methods to quantitate either SP-A (A) or SP-B (B) mRNA. Data are normalized to glyceraldehyde 3-phosphate dehydrogenase (GAPDH) mRNA level and expressed as a percent of untreated control. Data shown are the means \pm S.D. of three separate experiments. Significance was determined using a repeated measures one-way ANOVA with a Dunnett post test. a, $\mathrm{p}<0.05, \mathrm{~b}, \mathrm{p}<0.01$ compared to $\mathrm{H}_{2} \mathrm{O}_{2}$ only.

\section{A}

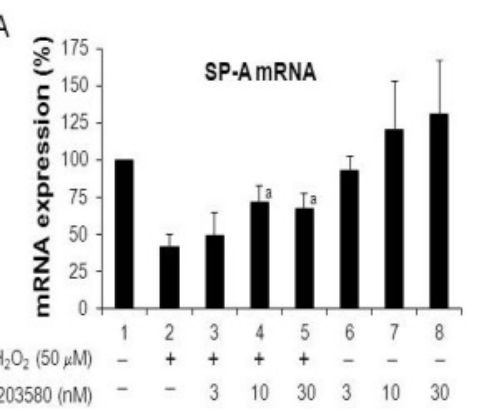

B

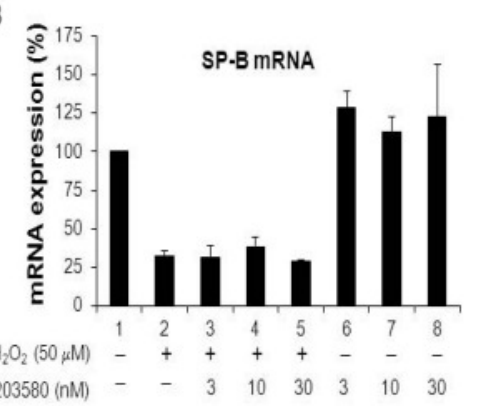

Fig. 7. Effect of $\mathrm{SB} 203580$ on $\mathrm{H}_{2} \mathrm{O}_{2}$-induced decrease in SP-A and SP-B gene expression. H441 cells were treated for 1 hour with various concentrations of SB203580 and then incubated for an additional 24 hours in the absence or presence of $\mathrm{H}_{2} \mathrm{O}_{2}$. Total RNA was then isolated, and qRT-PCR was performed as described under Methods to quantitate either SP-A (A) or SP-B (B) mRNA. Data are normalized to glyceraldehyde 3-phosphate dehydrogenase (GAPDH) mRNA level and expressed as a percent of untreated control. Data shown are the means \pm S.D. of three separate experiments. Significance was determined using a repeated measures one-way ANOVA with a Dunnett post test. a, $\mathrm{p}<0.01$ compared to $\mathrm{H}_{2} \mathrm{O}_{2}$ only.

\section{MAPK family members, ERK and p38 MAPK are involved in the $\mathrm{H}_{2} \mathrm{O}_{2}$-mediated decrease in}

$S P-A$ and $S P-B$ mRNA levels

Since ROS have been reported to activate MAPKs [10], we investigated whether MAPK signaling was associated with $\mathrm{H}_{2} \mathrm{O}_{2}$-induced inhibition of SP-A and SP-B gene expression using specific inhibitors of different MAPK family members. U0126 is a specific inhibitor of MEK1/2 which phosphorylates and activates the ERK1/2 family of MAPKs [24]. Treatment with U0126 (0.03-0.3 $\mu \mathrm{M})$ blocked the $\mathrm{H}_{2} \mathrm{O}_{2}$-mediated reduction in SP-A gene expression in a concentration-dependent manner (Fig. 6A) and partially blocked the $\mathrm{H}_{2} \mathrm{O}_{2}$-mediated reduction in SP-B expression (Fig. 6B). SB203580, an inhibitor of p38 MAPKs [25] (3-30 nM), partially blocked the $\mathrm{H}_{2} \mathrm{O}_{2}$-mediated reduction in SP-A mRNA (Fig. 7A), but had no effect on the $\mathrm{H}_{2} \mathrm{O}_{2}$-mediated reduction in SP-B mRNA (Fig. 7B). These concentrations of SB203580 were used based on previous published work demonstrating inhibition p38 MAPK in H441 cells [26]. SP600125, a specific inhibitor of the JNK family of MAPKs, had no effect on the $\mathrm{H}_{2} \mathrm{O}_{2}$-mediated reduction in SP-A or SP-B mRNA (data not shown). Since the ERK1/2 inhibitor blocked the $\mathrm{H}_{2} \mathrm{O}_{2}$-induced decrease in both SP-A and SP-B gene expression the effect of U0126 on the $\mathrm{H}_{2} \mathrm{O}_{2}$ induced decrease in TTF- 1 expression was examined. Interestingly U0126 partially blocked the effect of $\mathrm{H}_{2} \mathrm{O}_{2}$ on TTF-1 mRNA levels (data not shown). 


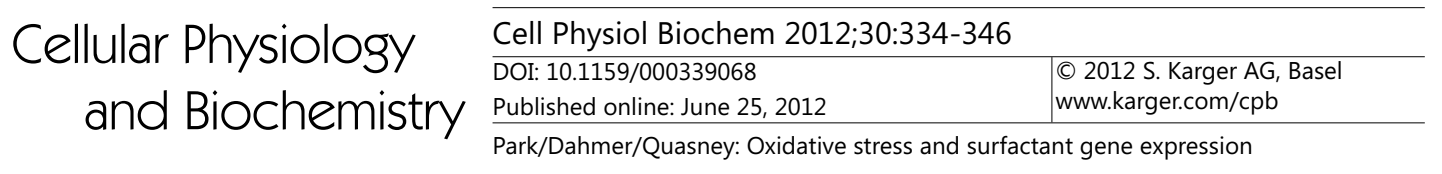

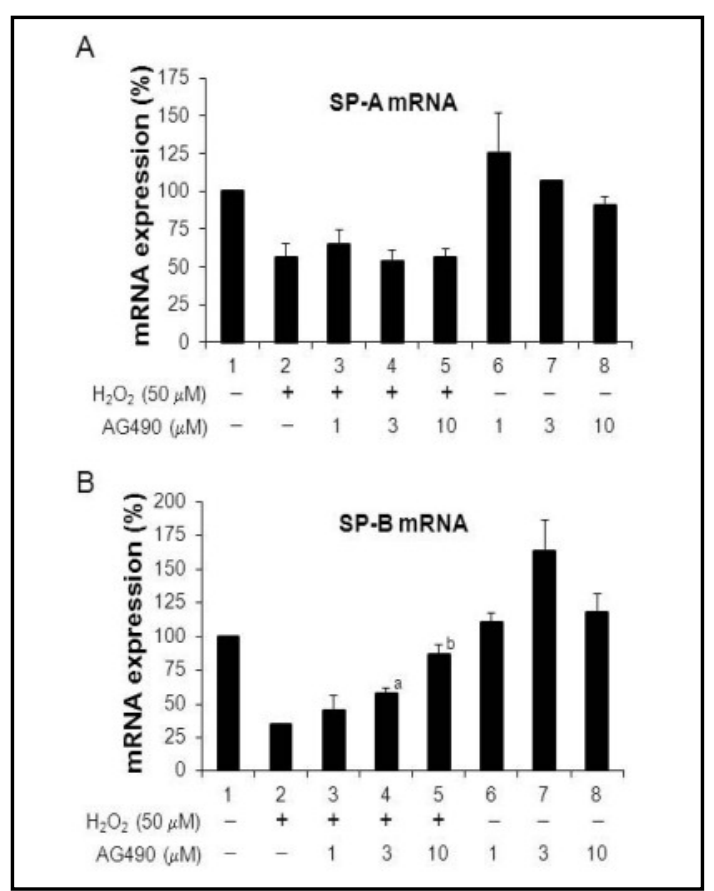

Fig. 8. Effect of AG490 on $\mathrm{H}_{2} \mathrm{O}_{2}$-induced decrease in SP-A and SP-B gene expression. H441 cells were treated for 1 hour with various concentrations of AG490 and then incubated for an additional 24 hours in the absence or presence of $\mathrm{H}_{2} \mathrm{O}_{2}$. Total RNA was then isolated, and qRT-PCR was performed as described under Methods to quantitate either SP-A (A) or SP-B (B) mRNA. Data are normalized to glyceraldehyde 3phosphate dehydrogenase (GAPDH) mRNA level and expressed as a percent of untreated control. Data shown are the means \pm S.D. of three separate experiments. Significance was determined using a repeated measures one-way ANOVA with a Dunnett post test. a, $\mathrm{p}<0.05, \mathrm{~b}, \mathrm{p}<0.01$ compared to $\mathrm{H}_{2} \mathrm{O}_{2}$ only.

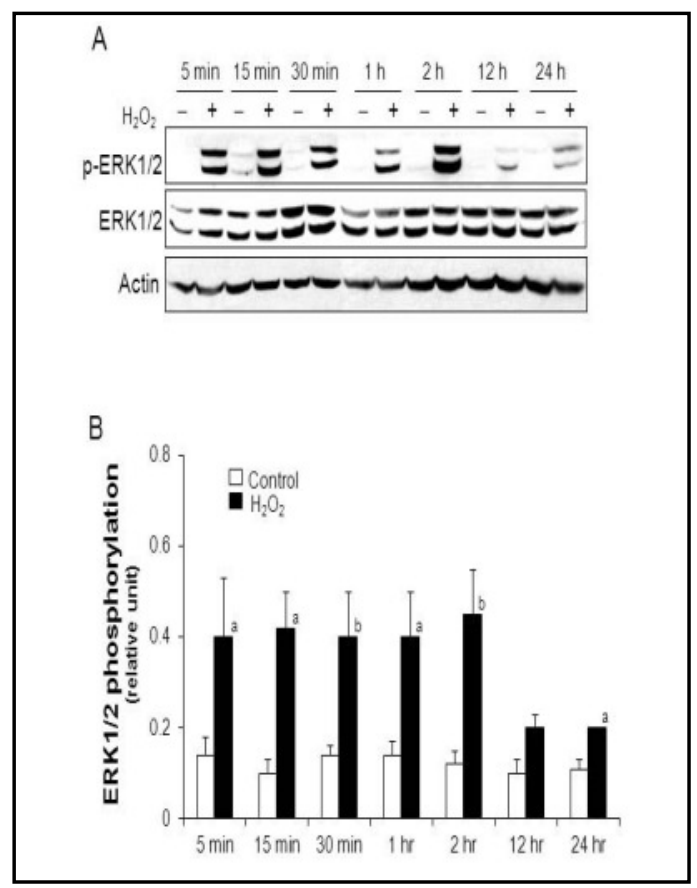

Fig. 9. Effect of $\mathrm{H}_{2} \mathrm{O}_{2}$ on the phosphorylation of ERK1/2. H441 cells were incubated in the presence or absence of $100 \mu \mathrm{M} \mathrm{H}_{2} \mathrm{O}_{2}$ for the indicated times. Cells lysates were prepared and used for immunoblotting with antibody specific for either phosphorylated ERK1/2 (p-ERK1/2), total ERK1/2 or actin as described under Methods. A: Shown is one representative immunoblot of demonstrating $\mathrm{H}_{2} \mathrm{O}_{2}$ mediated phosphorylation of ERK1/2. B: Protein bands were quantified using a STORM 860 phosphorImager and normalized to actin. Data shown are the means \pm S.D. of three separate experiments. Significance was determined using a paired t test. a, $\mathrm{p}<0.05, \mathrm{~b}, \mathrm{p}<0.01$ versus untreated controls.

The JAK-STAT pathway is associated with $\mathrm{H}_{2} \mathrm{O}_{2}$-mediated inhibition of SP-B but not SP-A gene expression

Previous studies have demonstrated that the JAK2-STAT3 signaling pathway is involved in $\mathrm{H}_{2} \mathrm{O}_{2}$ signaling $[11,12,27]$. To determine whether this signaling pathway plays a role in the observed $\mathrm{H}_{2} \mathrm{O}_{2}$-mediated decrease in SP-A and SP-B mRNA levels, $\mathrm{H} 441$ cells were treated with AG490 a well-known, specific, inhibitor of JAK2/3 [28] in the presence or absence of $\mathrm{H}_{2} \mathrm{O}_{2}$. As shown in Figure 8A, the $\mathrm{H}_{2} \mathrm{O}_{2}$-mediated decrease in SP-A mRNA levels was not affected by AG490. In contrast, the $\mathrm{H}_{2} \mathrm{O}_{2}$-mediated decrease in SP-B mRNA was blocked by AG490 in concentration-dependent manner with $10 \mu \mathrm{M}$ AG490 almost completely preventing the effect of $\mathrm{H}_{2} \mathrm{O}_{2}$ (Fig. 8B) suggesting that the JAK-STAT pathway is involved in $\mathrm{H}_{2} \mathrm{O}_{2}$-mediated reduction in SP-B, but not SP-A mRNA.

\section{$\mathrm{H}_{2} \mathrm{O}_{2}$ stimulates phosphorylation of ERK1/2, p38 MAPK and STAT3}

To determine whether $\mathrm{H}_{2} \mathrm{O}_{2}$ activates the signaling pathways suggested by the kinase inhibitors studies, we examined the effects of $\mathrm{H}_{2} \mathrm{O}_{2}$ on the phosphorylation of ERK1/2, p38 MAPK and STAT3. Protein lysates from $\mathrm{H}_{2} \mathrm{O}_{2}$-treated $\mathrm{H} 441$ cells were analyzed by immunoblotting using antibodies specific for phosphorylated forms of the indicated kinases. $\mathrm{H}_{2} \mathrm{O}_{2}$ treatment resulted in a rapid increase in ERK1/2 and p38 MAPK phosphorylation. The increase in phosphorylated ERK1/2 (pERK1/2) was evident at 5 min, sustained for at least $2 \mathrm{hr}$, 


\section{Cellular Physiology $\quad$ Cell Physiol Biochem 2012;30:334-346

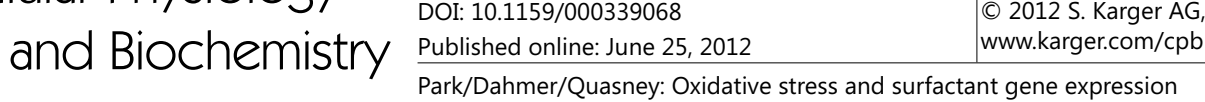

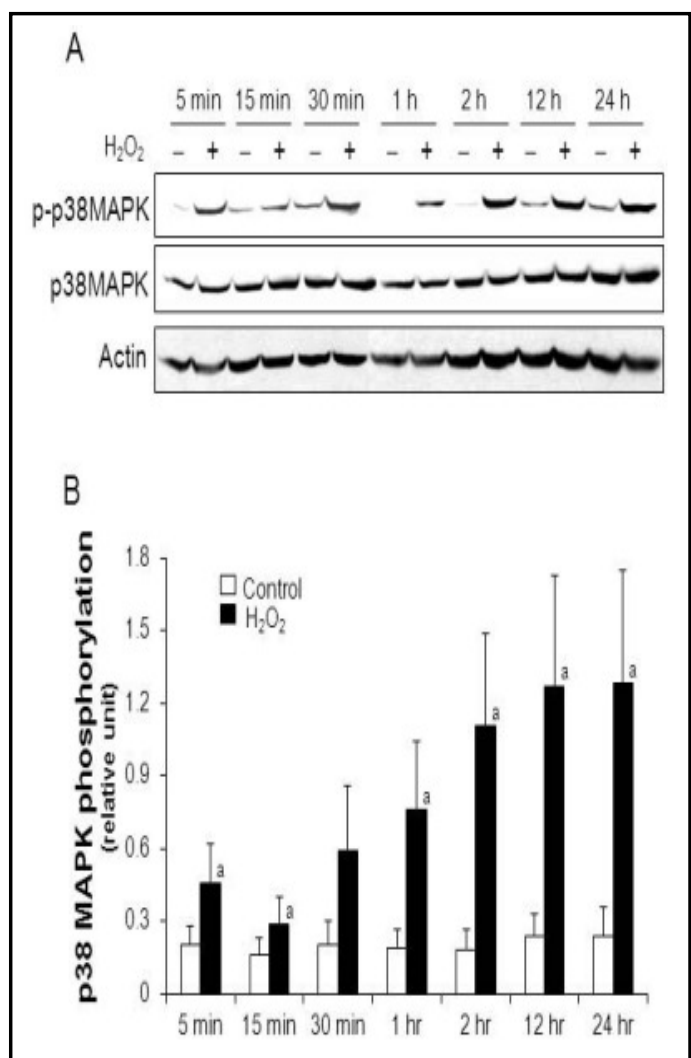

Fig. 10. Effect of $\mathrm{H}_{2} \mathrm{O}_{2}$ on the phosphorylation of $\mathrm{p} 38$ MAPK. H441 cells were incubated in the presence or absence of $100 \mu \mathrm{M} \mathrm{H}_{2} \mathrm{O}_{2}$ for the indicated times. Cell lysates were prepared as described under Methods and used for immunoblotting with antibody specific for either phosphorylated p38 MAPK (p-p38 MAPK), total p38 MAPK, or actin. A: Shown is one representative immunoblot demonstrating $\mathrm{H}_{2} \mathrm{O}_{2}$ mediated phosphorylation of p38 MAPK. B: Protein bands were quantified using a STORM 860 phosphorImager and normalized to actin. Data shown are the means \pm S.D. of three separate experiments. Significance was determined using a paired $t$ test. a, $\mathrm{p}<0.05$ versus untreated controls.

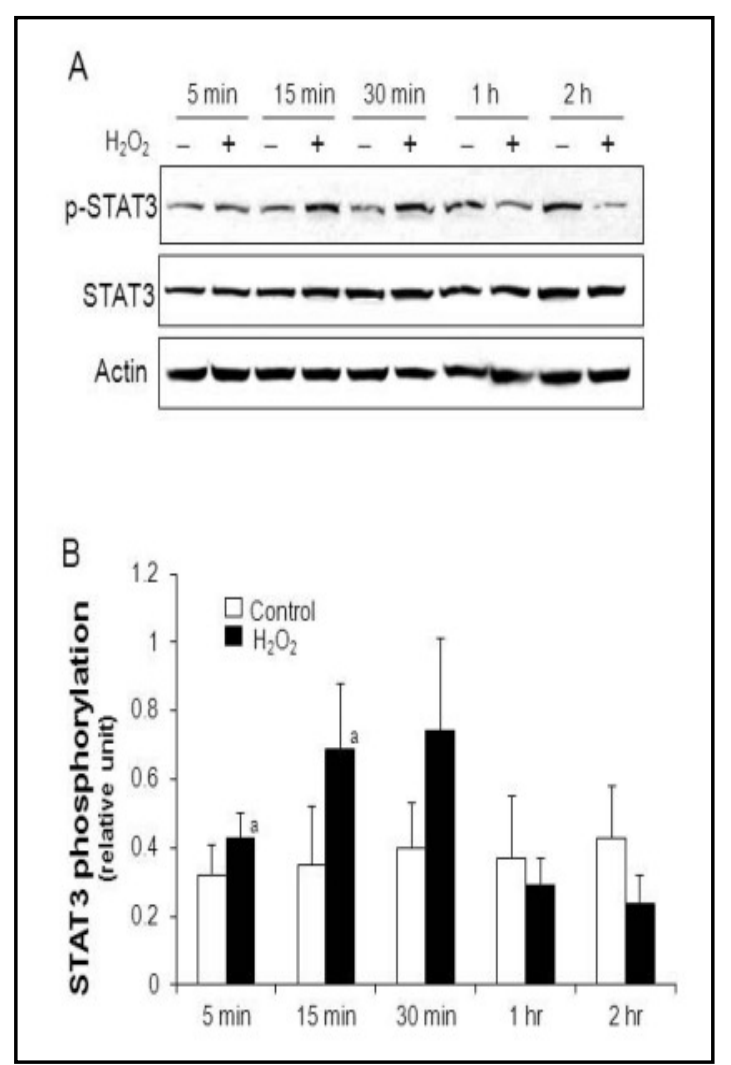

Fig. 11. Effect of $\mathrm{H}_{2} \mathrm{O}_{2}$ on the phosphorylation of STAT. H441 cells were incubated in the presence or absence of $100 \mu \mathrm{M} \mathrm{H}_{2} \mathrm{O}_{2}$ for the indicated times. Cell lysates were prepared as described under Methods and used for immunoblotting with antibody specific for either STAT phosphorylated on Tyr 705 (p-STAT), total STAT, or actin. A: Shown is one representative immunoblot demonstrating $\mathrm{H}_{2} \mathrm{O}_{2}$ mediated phosphorylation of STAT. B: Protein bands were quantified using a STORM 860 phosphorImager and normalized to actin. Data shown are the means \pm S.D. of three separate experiments. Significance was determined using a paired t test. a, $\mathrm{p}<0.05$ versus untreated controls.

and returned to almost basal levels by $12 \mathrm{~h}$ (Fig. 9). $\mathrm{H}_{2} \mathrm{O}_{2}$ treatment also rapidly stimulated p38 MAPK phosphorylation (p-p38 MAPK), however phosphorylation of p38 MAPK was sustained for at least $24 \mathrm{hr}$ (Fig. 10). We also examined the phosphorylation of the Tyr705 site of STAT3 (STAT3-Tyr705) (Fig. 11), using antibodies specific to this site ( $\alpha$-pSTAT3 [Y705]). The Tyr705 site demonstrated a modest, but statistically significant increase in phosphorylation at $5 \mathrm{~min}$ and $15 \mathrm{~min}$, however phosphorylation was decreased to basal levels at 1 hr (Fig. 11).

\section{Discussion}

This study is unique as it explores the signaling pathways involved in the ROS-mediated inhibition of SP-A and SP-B gene expression. The studies demonstrate that $\mathrm{H}_{2} \mathrm{O}_{2}$ treatment decreases mRNA levels of SP-A, SP-B, and ABCA3 in the human lung epithelial cell line H441, a human adenocarcinoma cell line used frequently to study the regulation of surfactant pro- 


\section{Cellular Physiology Cell Physiol Biochem 2012;30:334-346 \\ \begin{tabular}{ll|l} 
and Biochemistry & $\begin{array}{l}\text { DOI: 10.1159/000339068 } \\
\text { Published online: June 25, 2012 }\end{array}$ & $\begin{array}{l}\text { O 2012 S. Karger AG, Basel } \\
\text { www.karger.com/cpb }\end{array}$ \\
\cline { 2 - 3 } Park/Dahmer/Quasney: Oxidative stress and surfactant gene expression
\end{tabular}}

duction. $\mathrm{H}_{2} \mathrm{O}_{2}$ treatment also decreases binding of TTF-1, a transcription factor integrally involved in the transcriptional regulation of SP-A, SP-B, and ABCA3, to SP-A and SP-B promoter regions. In addition, mRNA and protein levels of TTF- 1 are decreased by $\mathrm{H}_{2} \mathrm{O}_{2}$ with a time course similar to that observed for effects on SP-A, SP-B and ABCA3. These data suggest that decreased expression of SP-A and SP-B after $\mathrm{H}_{2} \mathrm{O}_{2}$ treatment is mediated, at least in part, by reduced TTF-1 levels. The $\mathrm{H}_{2} \mathrm{O}_{2}$ induced decrease in binding of TTF- 1 to the SP-A and SP-B promoters may also be due to oxidation of TTF- 1 as previous studies have demonstrated that oxidation of TTF- 1 reduces DNA binding affinity $[29,30]$. Whether $\mathrm{H}_{2} \mathrm{O}_{2}$ also affects the level or DNA binding activity of other transcription factors involved in regulation of surfactant related genes remains to be investigated.

ROS activate multiple signaling pathways including mitogen-activated protein kinase (MAPK) [10] and Janus kinase (JAK)/signal transducers and activators of transcription (STAT) $[11,12]$ pathways. In addition, some of these pathways have also been implicated in inhibition of surfactant gene expression by other agents [31,32]. We used inhibitors of specific signaling pathways to determine whether any of the pathways might be involved in the effects of $\mathrm{H}_{2} \mathrm{O}_{2}$ on gene expression of SP-A and SP-B. Our results indicate that several of these pathways are involved with the effect of $\mathrm{H}_{2} \mathrm{O}_{2}$ on gene expression of surfactant related proteins. The ERK1/2 pathway appears to be involved in the $\mathrm{H}_{2} \mathrm{O}_{2}$-mediated inhibition of SP-A, SP-B, and TTF-1 gene expression. However the p38 MAPK pathway appears to be involved in the effect of $\mathrm{H}_{2} \mathrm{O}_{2}$ on SP-A, but not SP-B, gene expression. Conversely the JAK/STAT pathway appears to be involved in the $\mathrm{H}_{2} \mathrm{O}_{2}$ mediated decrease in SP-B, but not SP-A, mRNA. Our data indicates that all three of these pathways are activated by $\mathrm{H}_{2} \mathrm{O}_{2}$ treatment in $\mathrm{H} 441$ cells. Together these data indicate that these multiple pathways are differentially involved in the effect of $\mathrm{H}_{2} \mathrm{O}_{2}$ on SP-A and SP-B gene expression.

As discussed above, the ERK1/2 and p38 MAPK pathways both appear to be involved in the $\mathrm{H}_{2} \mathrm{O}_{2}$ effect on SP-A mRNA levels. Previous studies have implicated MAPK family members in inhibition of SP-A expression elicited by other agents. TNF- $\alpha$ and TPA, have been shown to inhibit SP-A gene expression in human lung epithelial cells via p38 MAPK and ERK MAPK signaling pathways, respectively [31,32]. The effect of $\mathrm{H}_{2} \mathrm{O}_{2}$ on SP-B appears to involve both the ERK1/2 and the JAK/STAT pathways. That there are overlapping and different pathways involved in the $\mathrm{H}_{2} \mathrm{O}_{2}$ mediated inhibition of SP-A and SP-B is not surprising as there is also overlap and differences in the factors that regulate transcription of these genes. In addition it is possible that some of the effects of $\mathrm{H}_{2} \mathrm{O}_{2}$ may be mediated by changes to the stability of the mRNA, which could also vary between SP-A and SP-B, and was not examined in this study.

There are several limitations to this study. First, H441 cells are a human pulmonary adenocarcinoma cell line; although this cell line has been used extensively to study surfactant synthesis, the effect of $\mathrm{H}_{2} \mathrm{O}_{2}$ on normal human pulmonary epithelial cells remains to be determined. Second, while we demonstrated the effect of $\mathrm{H}_{2} \mathrm{O}_{2}$ on surfactant protein mRNA levels, we did not show the protein levels. Indeed, SP-A protein levels were also reduced (data not shown) but protein levels of SP-B are very low in these cells despite detectable mRNA levels, and we could not evaluate the effect of $\mathrm{H}_{2} \mathrm{O}_{2}$ on SP-B protein levels. Finally, although we demonstrate $\mathrm{H}_{2} \mathrm{O}_{2}$ decreases TTF- 1 message and protein levels we did not evaluate the effect of $\mathrm{H}_{2} \mathrm{O}_{2}$ on TTF- 1 binding affinity, although data published by others suggest that binding affinity is also reduced by oxidation $[29,30]$. Further studies will help better elucidate these mechanisms of ROS inhibition of surfactant production.

It is still unclear how the activation of the indicated signaling pathways affects the transcription of SP-A and SP-B. The ERK1/2 pathway could affect the levels of SP-A and SP-B by changing the level or activity of required transcription factors, including TTF-1. Activation of the ERK1/2 pathway has been reported to inhibit TTF-1 transcriptional activity and stimulate TTF-1 phosphorylation [33]. In addition, Missero et al. demonstrated that ERK1/2 directly phosphorylates TTF- 1 in vitro, however it remains unclear whether phosphorylation of TTF1 by ERK1/2 affects its localization or function. The phosphorylation of SP-1, another transcription factor involved in transcriptional regulation of SP-A, SP-B and TTF-1, is associated 


\section{Cellular Physiology Cell Physiol Biochem 2012;30:334-346 \\ \begin{tabular}{ll|l} 
and Biochemistry & DOI: 10.1159/000339068 & $\begin{array}{l}\text { C 2012 S. Karger AG, Basel } \\
\text { www.karger.com/cpb }\end{array}$ \\
\cline { 2 - 3 } & Published online: June 25, 2012 & Park/Dahmer/Quasney: Oxidative stress and surfactant gene expression
\end{tabular}}

with TNF- $\alpha$ inhibition of TTF-1 expression [34]. In addition, a number of kinases, including ERK1/2 phosphorylate SP-1, although the effect of phosphorylation of SP-1 on promoter activity appears dependent on the promoter context and cell type $[35,36]$. It is unclear how the JAK/STAT pathway is involved in decreasing SP-B expression, however, as the JAK/STAT pathway has also been reported to be involved in the glucocorticoid induced potentiation of IL-6 stimulated SP-B gene expression [37], it is likely that the specific context in which the pathway is activated is important for determining its overall effect on SP-B expression. Future studies will be required to investigate the regulation of other transcription factors involved in surfactant protein expression.

In conclusion, $\mathrm{H}_{2} \mathrm{O}_{2}$ inhibits SP-A, SP-B and ABCA3 gene expression, and stimulates SP-D gene expression, in lung epithelial cells. Furthermore, changes in SP-A and SP-B gene expression induced by $\mathrm{H}_{2} \mathrm{O}_{2}$ are likely to be due, at least in part, to a decrease in the level of TTF-1 mRNA and protein in $\mathrm{H}_{2} \mathrm{O}_{2}$ treated cells. A number of signaling pathways appear to be involved in the effect of $\mathrm{H}_{2} \mathrm{O}_{2}$ on SP-A and/or SP-B expression including the ERK1/2, the p38 MAPK, and the JAK/STAT signaling pathways. Together these results provide a more detailed understanding of the cellular mechanisms by which oxidative stress may affect SP-A and SPB gene expression.

\section{References}

1 Rooney SA, Young SL, Mendelson CR: Molecular and cellular processing of lung surfactant. FASEB J 1994;8:957-967.

2 Weaver TE, Conkright JJ: Function of surfactant proteins B and C. Annu Rev Physiol 2001;63:555-578.

3 Wright JR: Immunoregulatory functions of surfactant proteins. Nat Rev Immunol 2005;5:58-68.

4 Baughman RP, Sternberg RI, Hull W, Buchsbaum JA, Whitsett J: Decreased surfactant protein A in patients with bacterial pneumonia. Am Rev Respir Dis 1993;147:653-657.

5 Clark JC, Weaver TE, Iwamoto HS, Ikegami M, Jobe AH, Hull WM, Whitsett JA: Decreased lung compliance and air trapping in heterozygous SP-B-deficient mice. Am J Respir Cell Mol Biol 1997;16:46-52.

6 Lucas R, Verin AD, Black SM, Catravas JD: Regulators of endothelial and epithelial barrier integrity and function in acute lung injury. Biochem Pharmacol 2009;77:1763-1772.

7 McCord JM: Oxygen-derived radicals: a link between reperfusion injury and inflammation. Fed Proc 1987;46:2402-2406.

8 Rahman I: Oxidative stress and gene transcription in asthma and chronic obstructive pulmonary disease: antioxidant therapeutic targets. Curr Drug Targets Inflamm Allergy 2002;1:291-315.

9 Ward PA: Oxidative stress: acute and progressive lung injury. Ann N Y Acad Sci 2010;1203:53-59.

10 Martindale JL, Holbrook NJ: Cellular response to oxidative stress: signaling for suicide and survival. J Cell Physiol 2002;192:1-15.

11 Carballo M, Conde M, El Bekay R, Martin-Nieto J, Camacho MJ, Monteseirin J, Conde J, Bedoya FJ, Sobrino F: Oxidative stress triggers STAT3 tyrosine phosphorylation and nuclear translocation in human lymphocytes. J Biol Chem 1999;274:17580-17586.

12 Simon AR, Rai U, Fanburg BL, Cochran BH: Activation of the JAK-STAT pathway by reactive oxygen species. Am J Physiol 1998;275:C1640-1652.

13 Oosting RS, van Greevenbroek MM, Verhoef J, van Golde LM, Haagsman HP: Structural and functional changes of surfactant protein A induced by ozone. Am J Physiol 1991;261:L77-83.

14 Rodriguez-Capote K, Manzanares D, Haines T, Possmayer F: Reactive oxygen species inactivation of surfactant involves structural and functional alterations to surfactant proteins SP-B and SP-C. Biophys J 2006;90:2808-2821.

15 Khalak R, Huyck HL, Pryhuber GS: Antagonistic effects of pyrrolidine dithiocarbamate and N-acetyl-L-cysteine on surfactant protein A and B mRNAs. Exp Lung Res 1999;25:479-493.

16 Yan C, Naltner A, Conkright J, Ghaffari M: Protein-protein interaction of retinoic acid receptor alpha and thyroid transcription factor-1 in respiratory epithelial cells. J Biol Chem 2001;276:21686-21691.

17 Bohinski RJ, Di Lauro R, Whitsett JA: The lung-specific surfactant protein B gene promoter is a target for thyroid transcription factor 1 and hepatocyte nuclear factor 3 , indicating common factors for organ-specific gene expression along the foregut axis. Mol Cell Biol 1994;14:5671-5681.

18 Das A, Boggaram V: Proteasome dysfunction inhibits surfactant protein gene expression in lung epithelial cells: mechanism of inhibition of SP-B gene expression. Am J Physiol Lung Cell Mol Physiol 2007;292:L7484 . 


\section{Cellular Physiology and Biochemistry

\begin{tabular}{l|l}
\hline Cell Physiol Biochem 2012;30:334-346 \\
\hline $\begin{array}{l}\text { DOI: 10.1159/000339068 } \\
\text { Published online: June 25, } 2012\end{array}$ \\
\hline $\begin{array}{l}\text { Park/Dahmer/Quasney: Oxidative stress and surfactant gene expression } \\
\text { www.karger.com/cpb }\end{array}$
\end{tabular}

19 Na SI, Lee MY, Heo JS, Han HJ: Hydrogen peroxide increases [3H]-2-deoxyglucose uptake via MAPKs, cPLA2, and NF-kappaB signaling pathways in mouse embryonic stem cells. Cell Physiol Biochem 2007;20:10071018.

20 Lee WC, Choi CH, Cha SH, Oh HL, Kim- YK: Role of ERK in hydrogen peroxide-induced cell death of human glioma cells. Neurochem Res 2005;30:263-270.

21 Besnard V, Xu Y, Whitsett JA: Sterol response element binding protein and thyroid transcription factor-1 (Nkx2.1) regulate Abca3 gene expression. Am J Physiol Lung Cell Mol Physiol 2007;293:L1395-405.

22 Boggaram V, Chandru H, Gottipati KR, Thakur V, Das A, Berhane K: Transcriptional regulation of SP-B gene expression by nitric oxide in H441 lung epithelial cells. Am J Physiol Lung Cell Mol Physiol 2010;299:L252262.

23 Yoshida I, Ban N, Inagaki N: Expression of ABCA3, a causative gene for fatal surfactant deficiency, is up-regulated by glucocorticoids in lung alveolar type II cells. Biochem Biophys Res Commun 2004;323:547-555.

24 Favata MF, Horiuchi KY, Manos EJ, Daulerio AJ, Stradley DA, Feeser WS, Van Dyk DE, Pitts WJ, Earl RA, Hobbs F, Copeland RA, Magolda RL, Scherle PA, Trzaskos JM: Identification of a novel inhibitor of mitogenactivated protein kinase kinase. J Biol Chem 1998;273:18623-18632.

25 Lee JC, Laydon JT, McDonnell PC, Gallagher TF, Kumar S, Green D, McNulty D, Blumenthal MJ, Heys JR, Landvatter SW: A protein kinase involved in the regulation of inflammatory cytokine biosynthesis. Nature 1994;372:739-746.

26 Berg T, Didon L, Barton J, Andersson O, Nord M: Glucocorticoids increase C/EBPbeta activity in the lung epithelium via phosphorylation. Biochem Biophys Res Commun 2005;334:638-645.

27 Park SK, Kim J, Seomun Y, Choi J, Kim DH, Han IO, Lee EH, Chung SK, Joo CK: Hydrogen peroxide is a novel inducer of connective tissue growth factor. Biochem Biophys Res Commun 2001;284:966-971.

28 Wang LH, Kirken RA, Erwin RA, Yu CR, Farrar WL: JAK3, STAT, and MAPK signaling pathways as novel molecular targets for the tyrphostin AG-490 regulation of IL-2-mediated T cell response. J Immunol 1999;162:3897-3904.

29 Arnone MI, Zannini M, Di Lauro R: The DNA binding activity and the dimerization ability of the thyroid transcription factor I are redox regulated. J Biol Chem 1995;270:12048-12055.

30 Kambe F, Nomura Y, Okamoto T, Seo H: Redox regulation of thyroid-transcription factors, Pax-8 and TTF-1, is involved in their increased DNA-binding activities by thyrotropin in rat thyroid FRTL-5 cells. Mol Endocrinol 1996;10:801-812.

31 Miakotina OL, Snyder JM: Signal transduction events involved in TPA downregulation of SP-A gene expression. Am J Physiol Lung Cell Mol Physiol 2004;286:L1210-1219.

32 Miakotina OL, Snyder JM: TNF-alpha inhibits SP-A gene expression in lung epithelial cells via p38 MAPK. Am J Physiol Lung Cell Mol Physiol 2002;283:L418-427.

33 Missero C, Pirro MT, Di Lauro R: Multiple ras downstream pathways mediate functional repression of the homeobox gene product TTF-1. Mol Cell Biol 2000;20:2783-2793.

34 Das A, Acharya S, Gottipati KR, McKnight JB, Chandru H, Alcorn JL, Boggaram V: Thyroid transcription factor-1 (TTF-1) gene: identification of ZBP-89, Sp1, and TTF-1 sites in the promoter and regulation by TNF-alpha in lung epithelial cells. Am J Physiol Lung Cell Mol Physiol 2011;301:L427-440.

35 Chu S, Ferro TJ: Sp1: regulation of gene expression by phosphorylation. Gene 2005;348:1-11.

36 Li L, He S, Sun JM, Davie JR: Gene regulation by Sp1 and Sp3. Biochem Cell Biol 2004;82:460-471.

37 Ladenburger A, Seehase M, Kramer BW, Thomas W, Wirbelauer J, Speer CP, Kunzmann S: Glucocorticoids potentiate IL-6-induced SP-B expression in H441 cells by enhancing the JAK-STAT signaling pathway. Am J Physiol Lung Cell Mol Physiol 2010;299:L578-584. 